\title{
Nesfatin-1 $1_{30-59}$ Injected
} Intracerebroventricularly Differentially Affects Food Intake Microstructure in Rats Under Normal Weight and Diet-Induced Obese Conditions

\author{
Philip Prinz ${ }^{1 \dagger}$, Pauline Teuffel ${ }^{1 \dagger}$, Vanessa Lembke ${ }^{1}$, Peter Kobelt ${ }^{1}$, \\ Miriam Goebel-Stengel ${ }^{2}$, Tobias Hofmann ${ }^{1}$, Matthias Rose ${ }^{1}$, Burghard F. Klapp ${ }^{1}$ and \\ Andreas Stengel ${ }^{1 *}$ \\ ${ }^{1}$ Division of General Internal and Psychosomatic Medicine, Charité Center for Internal Medicine and Dermatology, \\ Charité-Universitätsmedizin, Berlin, Germany, ${ }^{2}$ Department of Internal Medicine and Institute of Neurogastroenterology, \\ Martin-Luther-Krankenhaus, Berlin, Germany
}

OPEN ACCESS

Edited by:

James A. Carr

Texas Tech University, USA

Reviewed by:

Jacques Epelbaum,

French Institute of Health and Medical

Research, France

Guillaume Gourcerol,

Rouen University Hospital, France

${ }^{*}$ Correspondence:

Andreas Stengel

andreas.stenge/@charite.de

${ }^{\dagger}$ These authors have contributed equally to this work.

Specialty section:

This article was submitted to Neuroendocrine Science,

a section of the journal

Frontiers in Neuroscience

Received: 23 August 2015 Accepted: 19 October 2015 Published: 23 November 2015

Citation:

Prinz $P$, Teuffel $P$, Lembke $V$, Kobelt $P$, Goebel-Stengel M, Hofmann T, Rose M, Klapp BF and Stengel A (2015) Nesfatin-1 30-59 Injected Intracerebroventricularly Differentially Affects Food Intake Microstructure in Rats Under Normal Weight and

Diet-Induced Obese Conditions. Front. Neurosci. 9:422 doi: 10.3389/fnins.2015.00422
Nesfatin-1 is well-established to induce an anorexigenic effect. Recently, nesfatin-1 ${ }_{30}-59$, was identified as active core of full length nesfatin-1 $1_{1-82}$ in mice, while its role in rats remains unclear. Therefore, we investigated the effects of nesfatin-130-59 injected intracerebroventricularly (icv) on the food intake microstructure in rats. To assess whether the effect was also mediated peripherally we injected nesfatin-1 ${ }_{30-59}$ intraperitoneally (ip). Since obesity affects the signaling of various food intake-regulatory peptides we investigated the effects of nesfatin-1 ${ }_{30-59}$ under conditions of diet-induced obesity (DIO). Male Sprague-Dawley rats fed ad libitum with standard diet were icv cannulated and injected with vehicle $\left(5 \mu \mathrm{lddH_{2 }} O\right)$ or nesfatin- $1_{30-59}$ at $0.37,1.1$, and $3.3 \mu \mathrm{g}(0.1,0.3$, $0.9 \mathrm{nmol} / \mathrm{rat}$ ) and the food intake microstructure assessed using a food intake monitoring system. Next, naïve rats were injected ip with vehicle (300 $\mu$ l saline) or nesfatin-1 ${ }_{30-59}$ $(8.1,24.3,72.9 \mathrm{nmol} / \mathrm{kg})$. Lastly, rats were fed a high fat diet for 10 weeks and those

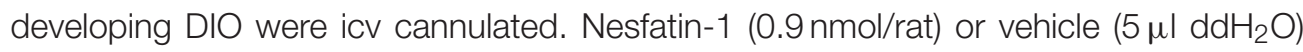
was injected icv and the food intake microstructure assessed. In rats fed standard diet, nesfatin-130-59 caused a dose-dependent reduction of dark phase food intake reaching significance at $0.9 \mathrm{nmol} / \mathrm{rat}$ in the period of $4-8 \mathrm{~h}$ post injection (-29\%) with the strongest reduction during the fifth hour ( $-75 \%)$, an effect detectable for $24 \mathrm{~h}(-12 \%, p<0.05$ vs. vehicle). The anorexigenic effect of nesfatin-1 ${ }_{30-59}$ was due to a reduction in meal size $(-44 \%, p<0.05)$, while meal frequency was not altered compared to vehicle. In contrast to icv injection, nesfatin-130-59 injected ip in up to 30-fold higher doses did not alter food intake. In DIO rats fed high fat diet, nesfatin-130-59 injected icv reduced food intake in the third hour post injection $(-71 \%)$, an effect due to a reduced meal frequency $(-27 \%$, $p<0.05)$, while meal size was not altered. Taken together, nesfatin-1 $1_{30-59}$ is the active core of nesfatin-1 1-82 and acts centrally to reduce food intake in rats. The anorexigenic effect depends on the metabolic condition with increased satiation (reduction in meal size) under normal weight conditions, while in DIO rats satiety (reduction in meal frequency) is induced.

Keywords: anorexigenic, brain-gut-axis, NUCB2, satiation, satiety 


\section{INTRODUCTION}

Nesfatin- $1_{1-82}$ was discovered in 2006 by Mori et al. as an anorexigenic peptide derived from the rat brain (Oh-I et al., 2006). It is post-translationally processed from the gene encoding nucleobindin2 (NUCB2) by the pro-hormone-convertase $1 / 3$ (Oh-I et al., 2006). NUCB2 consists of a 24 amino acid $\mathrm{N}$-terminal signal peptide and a protein structure containing 396 amino acids, but only the 396 amino acid sequence is cleaved into the $\mathrm{N}$-terminal nesfatin- $1_{1-82}$, nesfatin- $285-163$, and the C-terminal nesfatin-3166-396 (Oh-I et al., 2006). It was shown that nesfatin- $1_{1-82}$, but not nesfatin- $285-163$ or nesfatin$3_{166-396}$, reduces food intake and body weight gain in rats after injection into the third brain ventricle (Oh-I et al., 2006). The anorexigenic effect of central nesfatin- $1_{1-82}$ injected into the lateral, third and fourth brain ventricle, into the cisterna magna or directly into the lateral hypothalamic area, the paraventricular nucleus, or the dorsal vagal complex has been confirmed by various independent groups in several studies in rats (Yosten and Samson, 2009, 2010; Chen et al., 2012; Könczöl et al., 2012; Xia et al., 2012; Dong et al., 2014), mice (Atsuchi et al., 2010; Goebel et al., 2011), and goldfish (Gonzalez et al., 2010; Kerbel and Unniappan, 2012). This converging evidence points toward a physiological role of nesfatin- $1_{1-82}$ in the regulation of food intake.

Following these initial studies, the anorexigenic effect of nesfatin-1 was further characterized investigating the underlying food intake microstructure providing deeper insight into the mechanisms underlying the reduction of food intake (Geary, 2005). In mice, nesfatin- $1_{1-82}$ injected intracerebroventricularly (icv) reduced food intake with a delayed onset, an effect due to a reduction in meal size and meal frequency (Goebel et al., 2011) indicating a stimulatory effect on satiation and satiety (Strubbe and Woods, 2004). However, as species differences often play a role, this characterization is pending in rats.

Recently, the active core of nesfatin- $1_{1-82}$ has been identified, namely the mid fragment nesfatin-1 $1_{30-59}$ (Shimizu et al., 2009), while the $\mathrm{N}$-terminal nesfatin- $1_{1-29}$, and the C-terminal nesfatin- $1_{60-82}$ had no anorexigenic effect in mice (Shimizu et al., 2009; Stengel et al., 2012a). Although it is not clear yet whether this processing occurs in vivo, the characterization is an important step toward a better understanding of the ligand-receptor interaction, keeping in mind that the nesfatin1 receptor remains to be identified. Again, the characterization of the anorexigenic effect of nesfatin- $1_{30-59}$ is lacking for rats.

After the initial identification of NUCB2/nesfatin-1 in the brain, NUCB2 mRNA, and NUCB2/nesfatin-1 protein expression was also detected in the periphery (Stengel et al., 2009b). Interestingly, the major source of NUCB2/nesfatin-1 is the stomach with much higher NUCB2 mRNA expression levels compared to the brain (Stengel et al., 2009b) likely to act as a gut-brain peptide, a hypothesis supported by the observation that nesfatin-1 is able to cross the blood-brain barrier (Pan et al., 2007). Interestingly, on a cellular level NUCB2/nesfatin1 is co-expressed with ghrelin, the major orexigenic peptide signaling from the gut to the brain (Al Massadi et al., 2014), within the same cells in rats (Stengel et al., 2009b), and humans (Stengel et al., 2013a). This led to the assumption that these endocrine cells in the stomach can regulate food intake in both directions, either stimulate via the release of ghrelin or inhibit via the release of NUCB2/nesfatin-1 (Stengel and Taché, 2012b). However, data on the peripheral effects of nesfatin-1 on food intake are inconsistent. While several studies observed no effects of nesfatin-1 on food intake in rats (Stengel et al., 2009a) or mice (Goebel et al., 2011), one study described an anorexigenic effect of nesfatin- $1_{30-59}$ following intraperitoneal (ip) injection of high doses in mice (Shimizu et al., 2009). However, no data in rats exist so far.

The therapeutic potential of NUCB2/nesfatin-1 was discussed in several review articles (Stengel et al., 2013b), especially in the light of its leptin-independent signaling pathway (Oh-I et al., 2006), a hormone known to be less active under conditions of obesity (also known as leptin resistance) (Crujeiras et al., 2015). However, a detailed characterization of the food intake microstructure under conditions of diet-induced obesity (DIO), a well-established animal model for alimentary obesity (Lutz and Woods, 2012) frequently found in humans, has not been performed yet.

Therefore, the aims of the current study were to investigate the effect of icv injected nesfatin- $1_{30-59}$ on the food intake microstructure in normal weight rats. Next, we investigated whether the effect could also be observed following ip injection in rats. Lastly, to characterize the effect of nesfatin- $1_{30-59}$ on the food intake microstructure in obese animals, DIO rats fed a high fat diet were generated and nesfatin- $1_{30-59}$ injected icv.

\section{MATERIALS AND METHODS}

\section{Animals}

Male Sprague-Dawley rats (Harlan-Winkelmann Co., Borchen, Germany) weighing 280-350g were first group housed (4 rats/group) under controlled illumination $(06.00-18.00 \mathrm{~h})$ and temperature $\left(21-23^{\circ} \mathrm{C}\right)$. During this time rats were handled daily to become accustomed to the interaction with the investigators (daily control of body weight, light hand restraint for subsequent icv, or ip injections). Rats had ad libitum access to standard rodent diet (D12450B, Research Diets, Inc., Jules Lane, New Brunswick, NJ, USA) and tap water. Animal care and experimental procedures followed institutional ethics guidelines, conformed to the requirements and were approved by the state authority for animal research conduct (Landesamt für Gesundheit und Soziales Berlin, LaGeSo Berlin; animal protocol \# G 0131/11).

\section{Peptides}

Rat nesfatin-1 ${ }_{30-59}$ (Bachem AG, Weil am Rhein, Germany) was aliquoted in sterile distilled water and stored at $-80^{\circ} \mathrm{C}$ until further use. Purity was assessed by HPLC and mass spectroscopy (manufacturer's information). Directly before administration, rat nesfatin- $1_{30-59}$ was further diluted in sterile $\mathrm{ddH}_{2} \mathrm{O}$ for icv 
injection or in sterile $0.9 \%$ saline (B. Braun AG, Melsungen, Germany) for ip injection to reach the final concentrations detailed below.

\section{Diets}

For the induction of DIO, rats were fed a high fat diet (D12451, $45 \%$ calories from fat, $35 \%$ from carbohydrates, and $20 \%$ from protein, $4.7 \mathrm{kcal} / \mathrm{g}$ diet, Research Diets Inc.) for a period of 10 weeks. Control rats were kept on a standard rodent diet (D12450B, 10\% calories from fat, 70\% from carbohydrates, and $20 \%$ from protein, $3.9 \mathrm{kcal} / \mathrm{g}$ diet, Research Diets Inc.). Body weight and food intake were assessed daily. At the end of the 10 -week feeding period, the $50 \%$ of rats gaining the most body weight were selected as DIO.

\section{Intracerebroventricular Cannulation}

Rats were chronically icv cannulated as described before (Stengel et al., 2010a,b). Briefly, rats were anesthetized with an ip injection of $100 \mathrm{mg} / \mathrm{kg}$ ketamine (Ketanest ${ }^{\mathrm{TM}}$, Curamed, Karlsruhe, Germany) and $10 \mathrm{mg} / \mathrm{kg}$ xylazine (Rompun ${ }^{\mathrm{TM}}, 2 \%$, Bayer, Leverkusen, Germany). Afterwards, rats were placed in a stereotactic apparatus to implant a chronic 22-gauge guide cannula into the right lateral brain ventricle. The coordinates for the placement (from bregma: $0.8 \mathrm{~mm}$ posterior, $1.5 \mathrm{~mm}$ right lateral, and $3.5 \mathrm{~mm}$ ventral) were based on the atlas of Paxinos and Watson (2006). The chronic 22-gauge guide cannula was fixed by dental cement, anchored by four sterile screws (Plastic One Inc., Roanoke, VA, USA), and the wound was sutured. After the surgery, animals were housed individually and allowed to recover for 5 days. During this time, rats were handled daily to adapt to the icv injection procedure (light hand restraint for $1 \mathrm{~min}$ ). For the icv injection a 28-gauge cannula was connected to a $25 \mu \mathrm{l}$ Hamilton syringe by a PE-50 tube (BD intramedic polyethylene tubing, Clay Adams, NJ, USA) and a volume of $5 \mu \mathrm{l}$ was injected over a period of $1 \mathrm{~min}$ into the conscious rat.

The correct placement of the cannula was verified after the experiments by injecting $5 \mu \mathrm{l}$ of $0.1 \%$ toluidine blue and visualizing the spreading of the dye throughout the brain ventricular system. No animals had to be excluded due to erroneous placement of the cannula.

\section{Automated Food Intake Monitoring}

The BioDAQ episodic food intake monitoring system (BioDAQ, Research Diets Inc.) was used to investigate the food intake microstructure in rats. This system has been established before for the use in mice (Goebel et al., 2011) and recently also rats (Teuffel et al., 2015).

Rats were habituated for 1 week to the single housing (in regular housing cages with normal bedding and enrichment) and feeding from the hopper and as shown before quickly adapted to these conditions within 2-3 days indicated by normal food intake and regular body weight gain (Teuffel et al., 2015). Water was provided ad libitum from regular water bottles. Food was provided in low spill food hoppers placed on a balance. The "bridging phenomenon," that occurs when retained food spillage underneath the gate causes erroneous measurements, was observed very rarely by use of the diet described above and daily maintenance (cleaning) of the hoppers.

The BioDAQ food intake monitoring system weighs the hopper with food $( \pm 0.01 \mathrm{~g})$ every second and detects "not eating" as weight stable and "eating" as weight unstable. "Feeding bouts," defined as change in stable weight before and after an event, are recorded as vectors with starting time, duration and amount of food consumed (Teuffel et al., 2015). The feeding bouts are separated by an inter-bout interval (IBI) and meals can consist of one or more bouts. Furthermore, meals are separated by inter-meal intervals (IMI), in rats defined by a duration of $15 \mathrm{~min}$ (Teuffel et al., 2015). The minimum meal size in rats was defined as $0.01 \mathrm{~g}$ and therefore food intake was considered as one meal when the feeding bouts occurred within $15 \mathrm{~min}$ of the previous response and the content of food was equal to or greater than $0.01 \mathrm{~g}$ (Teuffel et al., 2015). If the interval between meals was greater than $15 \mathrm{~min}$, the feeding bouts were considered as a new meal. Meal parameters assessed in this study encompassed bout size (g/bout), meal size ( $\mathrm{g} / \mathrm{meal})$, bout frequency (number/period), meal frequency (number/period), inter-meal interval ( $\mathrm{min})$, meal duration ( $\mathrm{min} / \mathrm{meal})$, eating rate $(\mathrm{mg} / \mathrm{min})$, time spent in meals $(\%)$ as well as the satiety ratio ( $\mathrm{min} / \mathrm{g}$ food eaten) calculated using the parameters described above. These parameters were extracted from the software and visualized using the Data Viewer (BioDAQ Monitoring Software 2.3.07, Research Diets Inc.). Data analysis was performed in Excel (Microsoft). For better comparability between rats fed control or high fat diet, food intake was expressed in $\mathrm{kcal} / 300 \mathrm{~g}$ body weight (bw).

\section{EXPERIMENTAL PROTOCOLS}

\section{Food Intake Experiments}

In the first experiment icv cannulated rats fed ad libitum with standard rodent diet and accustomed to the food intake monitoring system as described above were icv injected with nesfatin-1 $1_{30-59}(0.1,0.3$, or $0.9 \mathrm{nmol} / \mathrm{rat})$ or vehicle $(5 \mu \mathrm{l}$ $\mathrm{ddH}_{2} \mathrm{O}$ ) directly before the onset of the dark phase. The dose of nesfatin-130-59 was based on our previous study in mice (Stengel et al., 2012a). The food intake microstructure was assessed over a period of $24 \mathrm{~h}$. The experiment was repeated once in a crossover design; rats were allowed to recover for 5 days in between the experiments. During two experiments, behavior was determined by observation of the locomotor activity and grooming (including washing and licking).

In order to assess whether the effect of nesfatin-130-59 is also mediated peripherally, naïve rats accustomed to the food intake monitoring system, handled for ip injections and fed ad libitum with standard rodent diet were injected ip with nesfatin$1_{30-59}(8.1,24.3$, or $72.9 \mathrm{nmol} / \mathrm{kg})$ or vehicle $(300 \mu \mathrm{l}$ saline $)$ directly before the dark phase started. These doses were based on the observation that higher doses are required peripherally compared to brain injections (Shimizu et al., 2009). Therefore, up to 30-times higher doses were used peripherally compared 
to our icv experiments. The microstructure was assessed over a period of $24 \mathrm{~h}$. This experiment was repeated once in a crossover design. Rats were allowed to recover for 5 days in between the experiments.

Since the hypothalamic regulation of food intake is altered under conditions of DIO (Velloso and Schwartz, 2011), we also investigated the effect of nesfatin- $1_{30-59}$ on the food intake microstructure in chronically icv cannulated DIO rats accustomed to the food intake monitoring system and fed a high fat diet. Nesfatin- $1_{30-59}(0.9 \mathrm{nmol} / \mathrm{rat}$, dose based on first

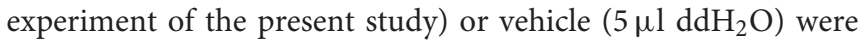
injected icv directly at the beginning of the dark phase and the food intake microstructure was assessed over a period of $24 \mathrm{~h}$. The experiment was repeated once in a crossover design and rats were allowed to recover for 5 days in between the experiments.

\section{Statistical Analysis}

Distribution of the data was determined by using the Kolmogorov-Smirnov test. Data are expressed as mean \pm sem and were analyzed by One-way analysis of variance (ANOVA) followed by Tukey post hoc test or Two-way or Threeway ANOVA followed by the Holm-Sidak method. Differences between groups were considered significant when $p<0.05$ (SigmaStat 3.1., Systat Software, San Jose, CA, USA).

\section{RESULTS}

\section{Nesfatin-1 $1_{30-59}$ Injected Intracerebroventricularly at the Onset of the Dark Phase Reduces Food Intake by Decreasing Meal Size in Normal Weight Rats}

Nesfatin- $1_{30-59}(0.1,0.3$, or $0.9 \mathrm{nmol} / \mathrm{rat})$ injected icv in normal weight rats fed ad libitum with standard rodent diet induced a dose-related reduction of dark phase food intake with a delayed onset between the $4-8 \mathrm{~h}$ period post injection and observed at

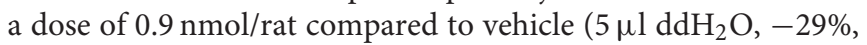
$p<0.05$; Figure 1A). Therefore, this dose was used for all further analyses. This reduction resulted in a decrease of cumulative food intake which was observed over the 24 -h measurement period $(-12 \%$ vs. vehicle, $p<0.05$; Figure 1B) indicating a long-lasting effect. Two-way ANOVA showed a significant influence of dose $\left[F_{(3,239)}=11.2, p<0.001\right]$ and time $\left[F_{(5,239)}=109.2\right.$, $p<0.001]$.

Analysis of hourly food intake indicated that the main anorexigenic effect occurred during the fifth hour post injection with a $-75 \%$ reduction of food intake following nesfatin$1_{30-59}$ compared to vehicle ( $p=0.05$; Figure 2 ). Moreover, parameters of the first meal were mostly unaffected by icv nesfatin-130-59 (Table 1) further pointing toward a delayed onset
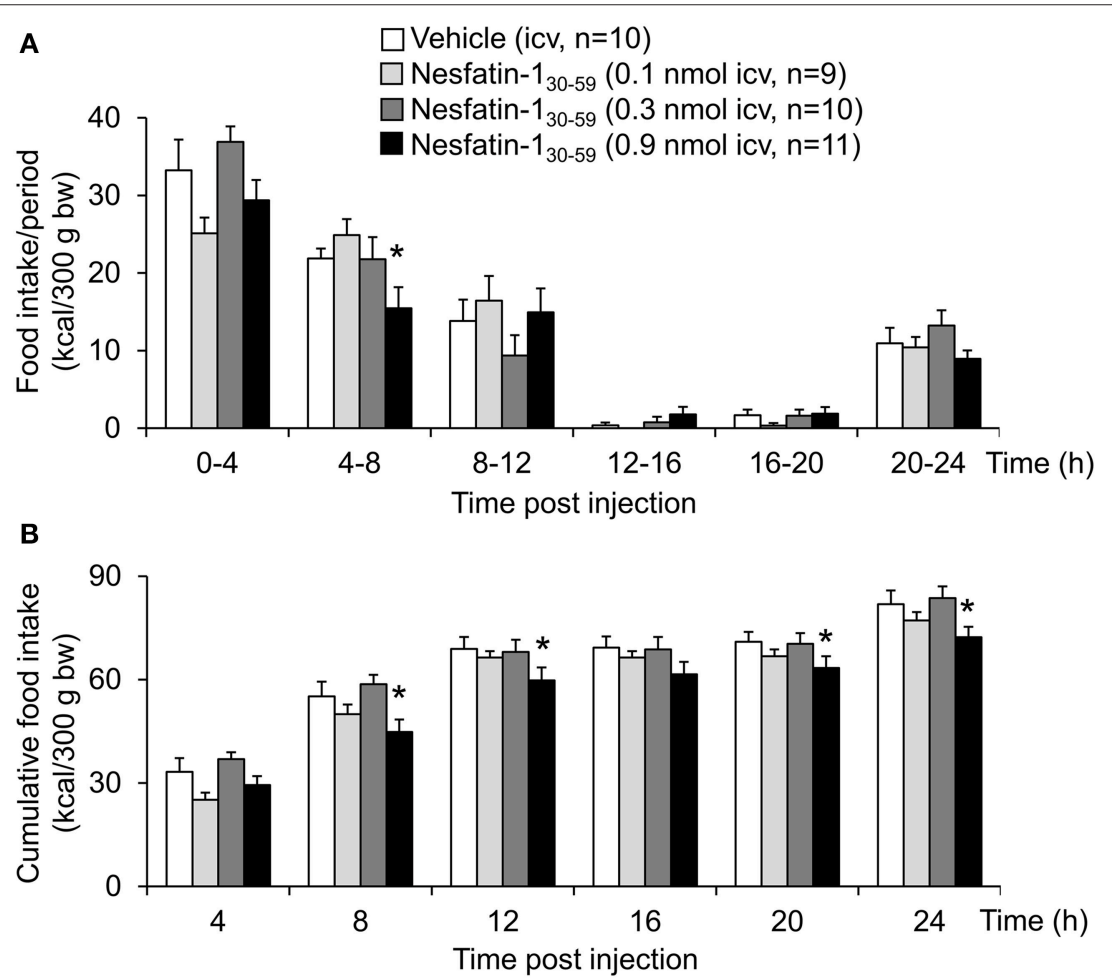

FIGURE 1 | Nesfatin-1 $\mathbf{3 0}_{\mathbf{3}} \mathbf{5 9}$ reduces food intake for $\mathbf{2 4} \mathbf{~ h}$ in ad libitum fed normal weight rats. Nesfatin-1 $30-59$ injected intracerebroventricularly $(0.1,0.3$, and $0.9 \mathrm{nmol} / \mathrm{rat}$ ) decreases dark phase food intake of standard rodent diet between the fourth and eighth hour and reduces cumulative food intake for $24 \mathrm{~h}$ post injection at a dose of $0.9 \mathrm{nmol} / \mathrm{rat}$. Food intake was measured by an automated episodic food intake monitoring system and expressed as food intake (kcal/300 $\mathrm{g}$ bw) $/ 4 \mathrm{~h}$ periods (A) and cumulative food intake over a period of $24 \mathrm{~h}$ (B). Each bar represents the mean \pm sem. ${ }^{*} p<0.05$ vs. vehicle. 


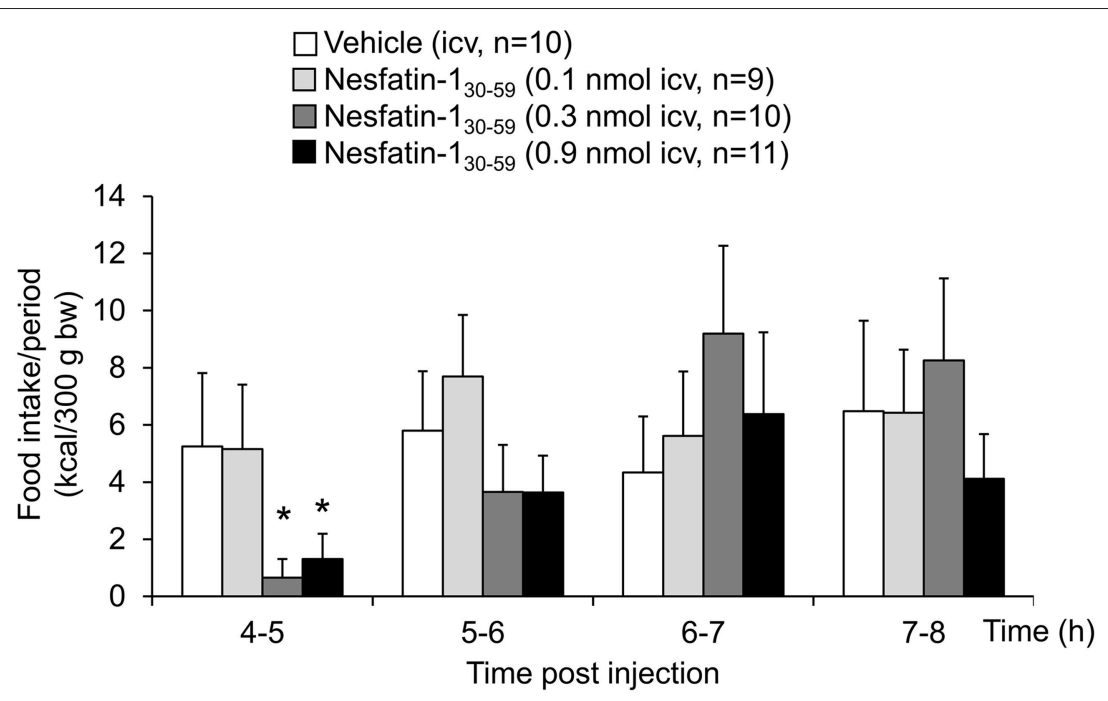

FIGURE 2 | Nesfatin-1 $\mathbf{3 0}_{\mathbf{3}} \mathbf{5 9}$ reduces food intake during the fifth hour post injection in normal weight rats. In rats fed ad libitum with standard rat diet, nesfatin-1 $30-59$ injected intracerebroventricularly $(0.1,0.3$, and $0.9 \mathrm{nmol} / \mathrm{rat})$ induces a dose-related decrease in dark phase food intake during the fifth hour post injection reaching significance at 0.3 and $0.9 \mathrm{nmol} / \mathrm{rat}$. Food intake is expressed as hourly food intake (kcal/300 $\mathrm{g}$ bw) during the $4-8 \mathrm{~h}$ period post injection. Each bar represents the mean \pm sem. ${ }^{*} p<0.05$ vs. vehicle.

TABLE 1 | Nesfatin-1 $30-59$ injected icv before the dark phase does not alter the parameters of the first meal in ad libitum fed normal weight rats.

\begin{tabular}{|c|c|c|}
\hline \multirow[t]{2}{*}{ Parameter } & \multicolumn{2}{|c|}{ Group } \\
\hline & $\begin{array}{c}\text { Vehicle } \\
\left(5 \mu l \text { ddH }_{2} \mathrm{O} \text { icv }\right)\end{array}$ & $\begin{array}{c}\text { Nesfatin-1 } 30-59 \\
\text { (0.9 nmol icv) }\end{array}$ \\
\hline $\begin{array}{l}\text { Latency to first meal } \\
\text { (min) }\end{array}$ & $2.09 \pm 0.55$ & $1.88 \pm 0.58$ \\
\hline $\begin{array}{l}\text { Size of first meal } \\
(\mathrm{kcal} / 300 \mathrm{~g} \mathrm{bw})\end{array}$ & $5.85 \pm 0.84$ & $7.73 \pm 0.90$ \\
\hline $\begin{array}{l}\text { Duration of first meal } \\
\text { (min) }\end{array}$ & $10.09 \pm 1.64$ & $13.54 \pm 1.68$ \\
\hline $\begin{array}{l}\text { Eating rate of first meal } \\
(\mathrm{cal} / 300 \mathrm{~g} \mathrm{bw} / \mathrm{min})\end{array}$ & $35.80 \pm 3.94$ & $29.69 \pm 2.86$ \\
\hline Inter-meal interval (min) & $46.71 \pm 6.44$ & $69.32 \pm 4.59^{*}$ \\
\hline $\begin{array}{l}\text { Satiety ratio after first } \\
\text { meal (min/kcal/300 g } \\
\text { bw food eaten) }\end{array}$ & $9.16 \pm 1.53$ & $11.80 \pm 1.93$ \\
\hline
\end{tabular}

icv, intracerebroventricular; mean \pm sem; $n=10-11 /$ group; ${ }^{*} p<0.05$.

of the anorexigenic action. However, the interval following the first meal was prolonged by nesfatin- $1_{30-59}$ compared to vehicle $(+48 \%, p<0.05$; Table 1$)$. Due to the significant reduction of food intake during the $4-8 \mathrm{~h}$ period post injection, the underlying food intake microstructure was analyzed during this period. Nesfatin- $1_{30-59}(0.9 \mathrm{nmol} / \mathrm{rat} \mathrm{icv})$ reduced meal size $(-45 \%, p<$ 0.05 ; Figure 3B), meal duration $(-54 \%, p<0.05$; Figure 3F), and the time spent in meals $(-41 \%, p<0.05$; Figure $3 \mathbf{H})$, while bout size (Figure 3A), bout frequency (Figure 3C), meal frequency (Figure 3D), inter-meal intervals (Figure 3E), and eating rate (Figure 3G) were not significantly affected compared to vehicle $(p>0.05)$. At the same time, the satiety ratio was increased following nesfatin-1 $30-59$ compared to vehicle injected icv $(+174 \%, p<0.05$; Figure 3I). Manual observation indicated no abnormal behavior following icv injection of nesfatin- $1_{30-59}$ (data not shown).

\section{Nesfatin-1 at the Onset of the Dark Phase Does Not Reduce Food Intake or Alter the Food Intake Microstructure of Normal Weight Rats}

Nesfatin- $1_{30-59}(8.1,24.3$, or $72.9 \mathrm{nmol} / \mathrm{kg}$, ip) injected at higher doses at the onset of the dark phase did not robustly reduce food intake either expressed as food intake/period or cumulative food intake compared to vehicle ( $p>0.05$; Table 2$)$. Only the highest dose $(72.9 \mathrm{nmol} / \mathrm{kg}$, ip) led to a slight and short-lasting reduction of food intake during the seventh hour post injection compared to vehicle $(p<0.05)$ that did not translate into a reduction of cumulative food intake ( $p>0.05$; Table 2). Also analysis of the food intake microstructure in the $4-8 \mathrm{~h}$ period (the period when nesfatin- $1_{30-59}$ injected icv exerted its main effects) indicated no alterations of microstructural parameters compared to vehicle injected ip ( $p>0.05$; Table 3). Lastly, parameters of the first meal were not affected by nesfatin-1 $1_{30-59}$ injected ip compared to control ( $p>0.05$; Table 4).

\section{Nesfatin-1 $1_{30-59}$ Injected Intracerebroventricularly at the Onset of the Dark Phase Reduces Food Intake by Decreasing Meal Frequency of Diet-induced-obese Rats Fed a High Fat Diet}

Rats fed a high fat diet (45\% calories from fat) for a period of 10 weeks developed DIO and gained significantly more body weight 
$\square$ Vehicle (icv, $\mathrm{n}=10$ )

Nesfatin-1 $1_{30-59}(0.9 \mathrm{nmol}$ icv, $\mathrm{n}=11)$
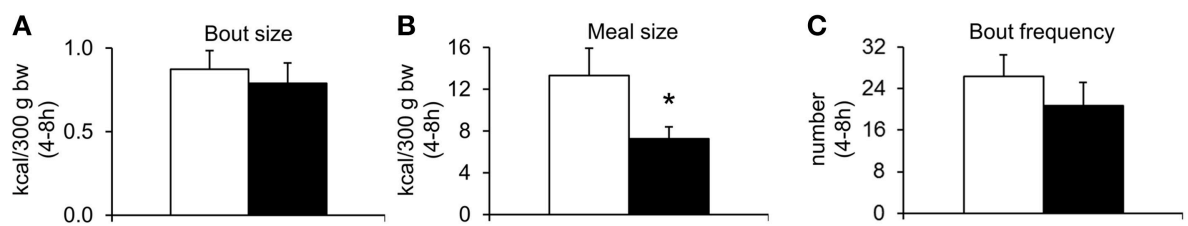

D

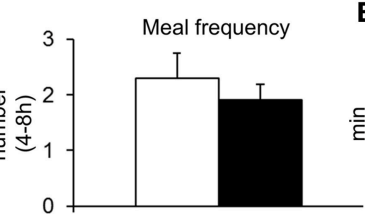

E

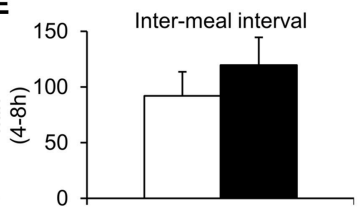

$\mathbf{F}$

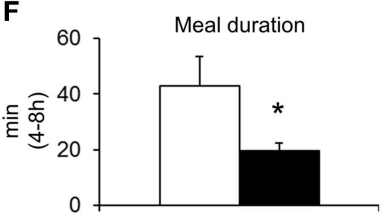

G Eating rate

\section{H}

Time spent in meals

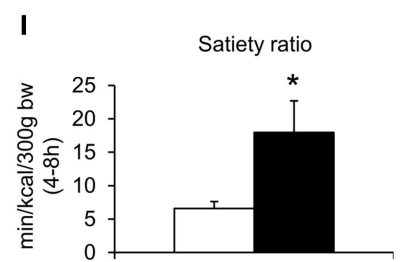

FIGURE 3 | Nesfatin-1 $\mathbf{3 0}_{\mathbf{3}} \mathbf{5 9}$ reduces meal size, while meal frequency is not altered in normal weight rats. Nesfatin-1 $30-59(0.1,0.3$, and $0.9 \mathrm{nmol} / \mathrm{rat})$ or vehicle $\left(5 \mu \mathrm{lddH_{2 }}\right.$ O) was injected intracerebroventricularly and the food intake microstructure assessed using an automated episodic food intake monitoring system. Due to the strongest reduction in food intake, the dose of $0.9 \mathrm{nmol} / \mathrm{rat}$ was used for all further analyses. During the period of $4-8 \mathrm{~h}$ post injection, nesfatin-1 $30-59$ reduced meal size (B), meal duration (F) and the time spent in meals $\mathbf{( H )}$, while bout size (A), bout frequency (C), meal frequency (D), inter-meal intervals $(\mathbf{E})$ and eating rate (G) were not altered compared to vehicle. The satiety ratio was increased following nesfatin-1 ${ }_{30-59}$ (I). Each bar represents the mean \pm sem. ${ }^{*} p<0.05$ vs. vehicle.

TABLE 2 | Nesfatin-1 $30-59$ injected ip before the dark phase does not alter food intake in ad libitum fed normal weight rats.

\begin{tabular}{|c|c|c|c|c|}
\hline Period & \multicolumn{4}{|c|}{ Group } \\
\hline $0-4 \mathrm{~h}$ & $41.15 \pm 2.20$ & $44.00 \pm 2.47$ & $44.42 \pm 2.21$ & $44.48 \pm 2.22$ \\
\hline $4-8 \mathrm{~h}$ & $27.70 \pm 2.09$ & $22.06 \pm 2.54$ & $25.80 \pm 2.24$ & $27.39 \pm 1.78$ \\
\hline $8-12 \mathrm{~h}$ & $13.15 \pm 2.03$ & $19.61 \pm 2.10$ & $15.56 \pm 2.47$ & $17.33 \pm 2.24$ \\
\hline $20-24 \mathrm{~h}$ & $12.51 \pm 1.28$ & $10.48 \pm 0.81$ & $12.54 \pm 1.78$ & $10.83 \pm 0.91$ \\
\hline \multicolumn{5}{|c|}{ CUMULATIVE FOOD INTAKE (KCAL/300 G BW) } \\
\hline $0-4 \mathrm{~h}$ & $41.15 \pm 2.20$ & $44.00 \pm 2.47$ & $44.42 \pm 2.21$ & $44.48 \pm 2.22$ \\
\hline $0-8 \mathrm{~h}$ & $68.84 \pm 2.56$ & $66.05 \pm 2.30$ & $70.23 \pm 2.33$ & $71.86 \pm 3.16$ \\
\hline $0-12 \mathrm{~h}$ & $81.99 \pm 2.76$ & $85.67 \pm 2.61$ & $85.79 \pm 2.74$ & $89.19 \pm 3.36$ \\
\hline
\end{tabular}

ip, intraperitoneal; mean \pm sem; $n=14$ /group; $p>0.05$.

compared to rats fed standard rodent diet (10\% calories from fat; $+21 \%$ at 10 weeks, $p<0.01$; Figure 4 ).

When injected icv in DIO rats, nesfatin- $1_{30-59}(0.9 \mathrm{nmol} / \mathrm{rat})$ induced a reduction of food intake during the $0-4 \mathrm{~h}$ period post injection compared to vehicle $\left(5 \mu \mathrm{lddH_{2 }} \mathrm{O},-40 \%, p<\right.$ 0.001; Figure 5A). This reduction resulted in a decrease of cumulative food intake over a period of $20 \mathrm{~h}$ ( $-13 \%$ vs. vehicle, $p<0.05$; Figure 5B). Two-way ANOVA indicated a significant influence of treatment $\left[F_{(1,131)}=36.3, p<0.001\right]$ and time $\left[F_{(5,131)}=53.4, p<0.001\right]$. Analysis of hourly food intake during the $0-4 \mathrm{~h}$ period showed that the main anorexigenic effect of nesfatin-1 $1_{30-59}$ occurred during the third and fourth 
TABLE 3 | Nesfatin-1 $30-59$ injected ip before the dark phase does not alter the food intake microstructure in the 4-8 $\mathrm{h}$ period post injection in ad libitum fed normal weight rats.

\begin{tabular}{|c|c|c|c|c|}
\hline \multirow[t]{2}{*}{ Parameter } & \multicolumn{4}{|c|}{ Group } \\
\hline & $\begin{array}{l}\text { Vehicle }(300 \mu \mathrm{I} \\
\text { saline ip) }\end{array}$ & $\begin{array}{l}\text { Nesfatin-1/30-59 } \\
\text { (8.1 nmol/kg ip) }\end{array}$ & $\begin{array}{l}\text { Nesfatin-1/30-59 } \\
\text { (24.3 nmol/kg ip) }\end{array}$ & $\begin{array}{l}\text { Nesfatin-1 } 30-59 \\
\text { (72.9 nmol/kg ip) }\end{array}$ \\
\hline Food intake 4-5 h (kcal/300 g bw) & $5.96 \pm 2.13$ & $6.09 \pm 2.15$ & $5.26 \pm 2.06$ & $8.35 \pm 2.87$ \\
\hline Food intake 5-6h (kcal/300 g bw) & $3.22 \pm 2.09$ & $4.21 \pm 1.98$ & $6.95 \pm 2.52$ & $12.20 \pm 3.31$ \\
\hline Food intake 6-7 h (kcal/300 g bw) & $14.18 \pm 3.34$ & $5.76 \pm 1.97$ & $6.63 \pm 2.89$ & $4.29 \pm 1.99^{\star}$ \\
\hline Food intake $7-8 \mathrm{~h}(\mathrm{kcal} / 300 \mathrm{~g} \mathrm{bw})$ & $4.34 \pm 2.00$ & $6.00 \pm 2.54$ & $6.97 \pm 2.25$ & $2.53 \pm 1.50$ \\
\hline Bout size 4-8h (kcal/300 g bw) & $0.86 \pm 0.06$ & $0.82 \pm 0.07$ & $0.87 \pm 0.04$ & $0.85 \pm 0.05$ \\
\hline Meal size 4-8h (kcal/300 g bw) & $17.01 \pm 2.39$ & $14.32 \pm 1.58$ & $15.35 \pm 2.25$ & $18.55 \pm 2.11$ \\
\hline Bout frequency 4-8h (number) & $32.07 \pm 3.39$ & $27.29 \pm 1.99$ & $31.00 \pm 2.86$ & $32.64 \pm 2.83$ \\
\hline Meal frequency 4-8h (number) & $1.93 \pm 0.22$ & $1.71 \pm 0.27$ & $2.00 \pm 0.23$ & $1.71 \pm 0.19$ \\
\hline Inter-meal interval 4-8h (min) & $143.61 \pm 31.10$ & $101.41 \pm 18.08$ & $147.27 \pm 27.32$ & $159.46 \pm 31.92$ \\
\hline Meal duration 4-8h (min) & $53.67 \pm 8.20$ & $47.36 \pm 7.52$ & $48.12 \pm 8.75$ & $57.40 \pm 7.42$ \\
\hline $\begin{array}{l}\text { Eating rate } 4-8 \mathrm{~h}(\mathrm{cal} / 300 \mathrm{~g} \\
\mathrm{bw} / \mathrm{min})\end{array}$ & $109.27 \pm 10.94$ & $123.77 \pm 11.05$ & $107.61 \pm 11.40$ & $125.47 \pm 18.96$ \\
\hline Time spent in meals 4-8h (\%) & $36.65 \pm 3.17$ & $29.40 \pm 3.94$ & $31.89 \pm 3.01$ & $35.49 \pm 3.43$ \\
\hline $\begin{array}{l}\text { Satiety ratio } 4-8 \mathrm{~h}(\mathrm{~min} / \mathrm{kcal} / 300 \mathrm{~g} \\
\text { bw food eaten) }\end{array}$ & $8.17 \pm 1.08$ & $7.73 \pm 1.66$ & $10.33 \pm 1.41$ & $8.47 \pm 10.4$ \\
\hline
\end{tabular}

ip, intraperitoneal; mean \pm sem; $n=14$ /group; * $p<0.05$ vs vehicle.

TABLE 4 | Nesfatin-1 $30-59$ injected ip before the dark phase does not alter parameters of the first meal in ad libitum fed normal weight rats.

\begin{tabular}{|c|c|c|c|c|}
\hline \multirow[t]{2}{*}{ Parameter } & \multicolumn{4}{|c|}{ Group } \\
\hline & $\begin{array}{c}\text { Vehicle }(300 \mu \mathrm{I} \\
\text { saline ip) }\end{array}$ & $\begin{array}{c}\text { Nesfatin-1 } 30-59 \\
\text { (8.1 nmol/kg ip) }\end{array}$ & $\begin{array}{l}\text { Nesfatin-1/30-59 } \\
\text { (24.3 nmol/kg ip) }\end{array}$ & $\begin{array}{l}\text { Nesfatin-1 } 30-59 \\
\text { (72.9 nmol/kg ip) }\end{array}$ \\
\hline Latency to first meal (min) & $4.83 \pm 2.24$ & $9.23 \pm 3.67$ & $4.74 \pm 1.84$ & $7.40 \pm 5.39$ \\
\hline Size of first meal (kcal/300 g bw) & $11.08 \pm 1.59$ & $7.70 \pm 0.85$ & $8.55 \pm 1.26$ & $14.00 \pm 2.92$ \\
\hline Duration of first meal (min) & $21.15 \pm 3.84$ & $16.95 \pm 3.24$ & $17.70 \pm 4.17$ & $29.35 \pm 8.89$ \\
\hline Eating rate of first meal (cal/300 g bw/min) & $156.85 \pm 12.37$ & $152.62 \pm 17.56$ & $134.24 \pm 13.45$ & $176.78 \pm 17.44$ \\
\hline Inter-meal interval (min) & $48.17 \pm 6.94$ & $36.54 \pm 4.90$ & $43.12 \pm 3.20$ & $49.28 \pm 7.17$ \\
\hline Satiety ratio after first meal (min/kcal/300 g bw food eaten) & $5.04 \pm 0.57$ & $5.72 \pm 1.19$ & $9.08 \pm 3.49$ & $4.40 \pm 0.57$ \\
\hline
\end{tabular}

ip, intraperitoneal; mean \pm sem; $n=14$ /group; $p>0.05$.

hour post injection $(-71$ and $-74 \%$, respectively, compared to vehicle, $p<0.05$; Figure 6) pointing toward a delayed effect. In line with this assumption, parameters of the first meal were not significantly altered following nesfatin- $1_{30-59}$ compared to vehicle (Table 5).

Based on the finding that nesfatin- $1_{30-59}$ already decreased food intake in DIO rats during the $0-4 \mathrm{~h}$ period post injection, the microstructure was analyzed during this period. Nesfatin$1_{30-59}(0.9 \mathrm{nmol} / \mathrm{rat}, \mathrm{icv})$ reduced bout frequency $(-33 \%, p<$ 0.05 ; Figure 7C), meal frequency $(-27 \%, p<0.05$; Figure 7D), and eating rate $(-35 \%, p<0.01$; Figure $7 \mathrm{G})$, while bout size (Figure 7A), meal size (Figure 7B), meal duration (Figure 7F), and the time spent in meals (Figure $7 \mathbf{H}$ ) were not significantly affected compared to vehicle $(p>0.05)$. Moreover, intermeal intervals $(+53 \%$, Figure $7 \mathbf{E})$ and the satiety ratio $(+81 \%$, Figure 7I) were increased following icv injection of nesfatin$1_{30-59}(p<0.01$ vs. vehicle).
The combined analysis of food intake data of rats fed control or high fat diet using Three-way ANOVA indicated a significant influence of diet $\left[F_{(1,257)}=83.5, p<0.001\right]$, time $\left[F_{(5,257)}=\right.$ $108.1, p<0.001]$, and interaction of diet and time $\left[F_{(5,257)}=\right.$ $10.6, p<0.001]$ as well as an interaction of treatment and time $\left[F_{(5,257)}=2.6, p<0.05\right]$.

\section{DISCUSSION}

In the present study we investigated the effect of nesfatin- $1_{30-59}$ on feeding behavior in rats under normal weight and dietinduced obese conditions. Nesfatin- $1_{30-59}$ injected icv reduced dark phase food intake in normal weight rats fed a standard rodent diet. This effect was delayed in onset as parameters of the first meal were not altered with a maximum reduction of food intake observed during the fifth hour post injection and long lasting as it resulted in a reduction of cumulative food intake over 


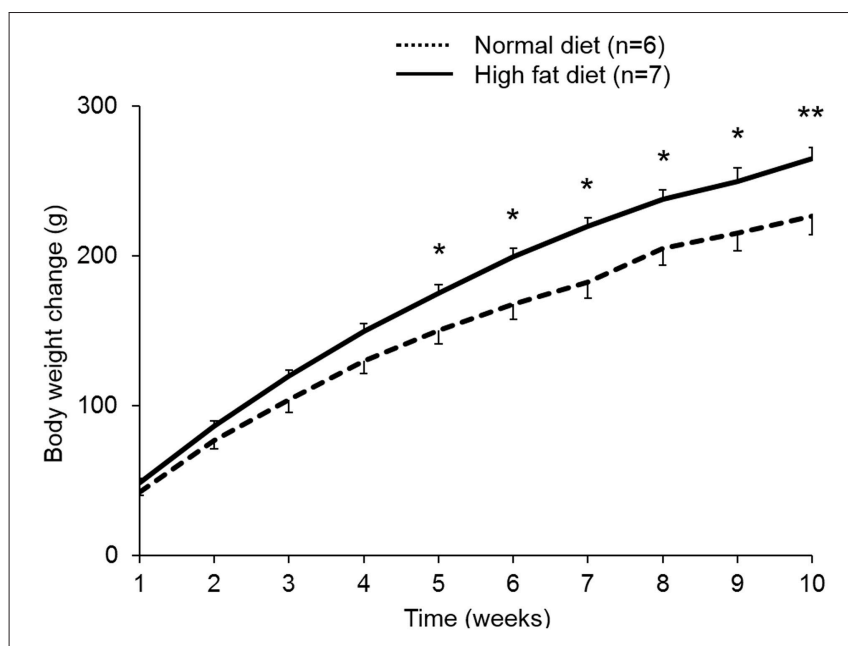

FIGURE 4 | Rats fed a high fat diet develop diet-induced obesity. Rats were ad libitum fed either a high fat diet (45\% calories from fat, 35\% from carbohydrates, and $20 \%$ from protein, $4.7 \mathrm{kcal} / \mathrm{g}$ ) or standard rodent diet $(10 \%$ calories from fat, $70 \%$ from carbohydrates, and $20 \%$ from protein, $3.9 \mathrm{kcal} / \mathrm{g}$ ) over a period of 10 weeks. Rats that gained most body weight ( $50 \%)$ were selected for the following experiments as diet-induced obese (DIO) rats. DIO rats showed greater body weight gain compared to rats fed standard rodent diet. Data are expressed as mean \pm sem. ${ }^{\star} p<0.05$ and ${ }^{\star *} p<0.01$ vs. vehicle.

the $24 \mathrm{~h}$ observation period. These data are in accordance with a previous study in rats where the main reduction following icv full length nesfatin- $1_{1-82}$ was observed during the third hour post injection and also observed over the whole measurement period of $6 \mathrm{~h}$ (Stengel et al., 2009a). The difference in the onset of action (third hour after nesfatin-1 $1_{1-82}$ vs. fifth hour after nesfatin$1_{30-59)}$ may be due to differential diffusion capacities following icv injection and-more importantly-differential interaction with the yet unknown nesfatin-1 receptor. Lastly, also the interaction with (an) additional receptor(s) has to be considered.

Interestingly, higher doses of nesfatin-1 $1_{30-59}$ were needed to induce an anorexigenic effect. While nesfatin- $1_{1-82}$ injected icv reduced food intake in rats following injection of $5 \mathrm{pmol}$, nesfatin-130-59 exerted an anorexigenic effect after icv injection of $0.9 \mathrm{nmol} / \mathrm{rat}$. This difference is likely to result from differential ligand-receptor interaction with full length nesfatin- $1_{1-82}$ being more potent to induce the food intake inhibitory effect at low doses. Whether the difference in potency is due to more selective binding of nesfatin- $1_{1-82}$ to the receptor, slower dissociation or a more potent stimulation of the receptor compared to nesfatin$1_{30-59}$ will have to be investigated in future studies. The effective dose observed here in rats is comparable to the anorexigenic doses described before in mice $(0.3$ and $0.9 \mathrm{nmol} /$ mouse nesfatin130-59 icv; Stengel et al., 2012a).

After establishing nesfatin- $1_{30-59}$ also as an active fragment of nesfatin- $1_{1-82}$ to reduce food intake in rats we investigated the underlying food intake microstructure. Nesfatin- $1_{30-59}$ injected icv reduced food intake by reducing meal size, while meal frequency and inter-meal intervals were not altered. This pattern indicates an increase of satiation (earlier termination of a meal), whereas satiety (later initiation of a new meal after one meal is completed) is not affected. This pattern is different from the one observed before for mice where satiety (reduction in meal frequency) was induced while satiation (meal size was not altered) was not affected by icv nesfatin-1 $1_{30-59}$ (Stengel et al., 2012a). This difference points toward species differences and highlights the need for cautious translation of results from one species to another. Interestingly, in mice full length nesfatin$1_{1-82}$ injected icv increased both satiation and satiety (Goebel et al., 2011). This different pharmacodynamics is likely due to a differential receptor binding of full length nesfatin- $1_{1-82}$ and its active core, nesfatin- $1_{30-59}$.

Early on, the downstream signaling of NUCB2/nesfatin1 has been investigated. It has been shown that oxytocin is involved in the mediation of nesfatin- $1_{1-82}$ 's anorexigenic effect as nesfatin-1 $1_{1-82}$ activates oxytocin containing neurons in the paraventricular nucleus of the hypothalamus (PVN) and central administration of the oxytocin-receptor antagonist, H4928 abolished the food intake reduction induced by nesfatin$1_{1-82}$ in rats (Maejima et al., 2009). Moreover, an involvement of proopiomelanocortin (POMC) and cocaine and amphetamineregulated transcript (CART) has been indicated as well based on the following observations: First, nesfatin-1 $1_{30-59}$ was shown to upregulate the mRNA expression of POMC and CART in mice (Shimizu et al., 2009). Second, blockade of $\alpha$-melanocyte stimulating hormone $(\alpha-\mathrm{MSH})$ signaling, a major anorexigenic cleavage product of POMC (Schwartz et al., 2000), using the melanocortin receptor 3/4 antagonist, SHU9119 also blocked nesfatin- $1_{1-82}$ 's anorexigenic effect (Oh-I et al., 2006). Third, brain ventricular injection of the melanocortin receptor $3 / 4$ agonist, MTII decreased food intake by reducing meal size, while no effect on meal frequency was observed (Azzara et al., 2002; Berthoud et al., 2006), resembling the pattern of action observed after icv injection of nesfatin- $1_{30-59}$ in the present study. Since oxytocin increases the release of POMC in the nucleus of the solitary tract (NTS), nesfatin- $1_{30-59}$ is likely to act via an oxytocin $\rightarrow \mathrm{POMC} \rightarrow \alpha-\mathrm{MSH} /$ melanocortin receptor $3 / 4$ pathway to inhibit food intake in rats.

Despite the fact that NUCB2/nesfatin-1 is predominantly expressed in the stomach (Stengel et al., 2009b), the role of peripheral NUCB2/nesfatin-1 is far from being clear. While one study reported an anorexigenic effect following ip injection of nesfatin-130-59 in mice (Shimizu et al., 2009), other studies in rats (Stengel et al., 2009a), or mice (Goebel et al., 2011) did not detect any effect. Similarly, in the present study we did not find an anorexigenic effect of nesfatin- $1_{30-59}$ injected ip in normal weight rats although up to 30 -fold higher doses were used. This difference may be due to species differences (mice vs. rats) or different doses used (up to $\sim 40 \mathrm{nmol} /$ mouse vs. $\sim 22 \mathrm{nmol} /$ rat in the present study). However, these findings clearly point toward a central mode of action of nesfatin- 1 to reduce food intake, while peripheral nesfatin-1 is likely to have a different main effect such as glucose control (Nakata and Yada, 2013).

Signaling of several food intake regulatory hormones is altered under conditions of obesity (Hellström, 2013). These changes encompass a decrease in circulating ghrelin levels (Ariyasu et al., 2002) which may represent a compensatory action to prevent further overeating. On the other side, the postprandial 

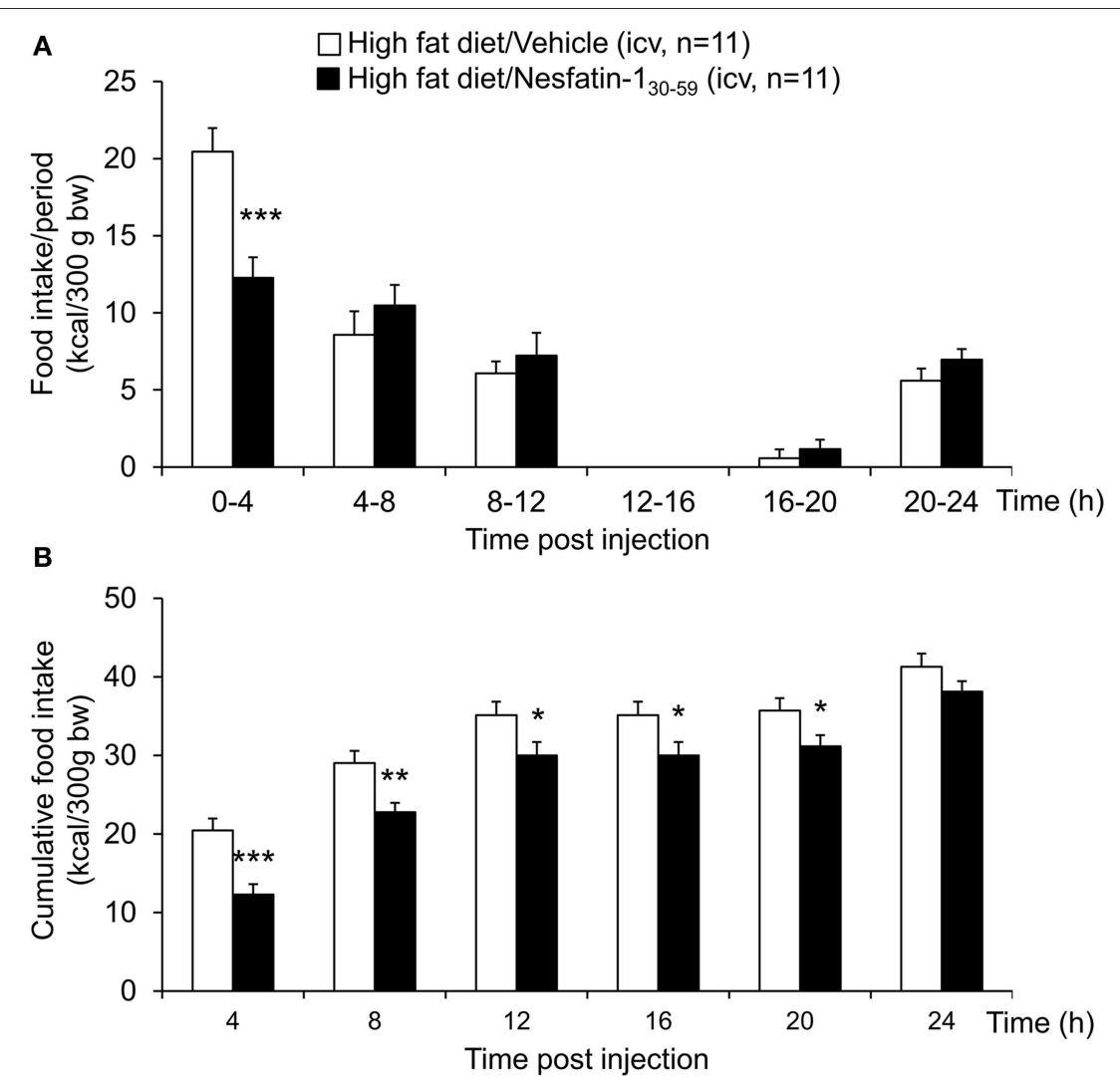

FIGURE 5 | Nesfatin-1 $\mathbf{3 0 - 5 9}$ reduces food intake for $\mathbf{8} \mathbf{h}$ in ad libitum fed diet-induced obese rats. Nesfatin-1 $30-59(0.9 \mathrm{nmol} / \mathrm{rat})$ injected intracerebroventricularly decreased dark phase food intake in the first $4 \mathrm{~h}$ period post injection, an effect that lasted for $8 \mathrm{~h}$ compared to vehicle (5 $\mu \mathrm{l}$ dd $\mathrm{H}_{2} \mathrm{O}$ ). Food intake was assessed using an automated episodic food intake monitoring system and expressed as food intake (kcal/300 $\mathrm{g}$ bw) $/ 4 \mathrm{~h} \mathrm{periods} \mathrm{(A)} \mathrm{and} \mathrm{cumulative} \mathrm{food}$ intake over a period of $24 \mathrm{~h}$ (B). Each bar represents the mean \pm sem. ${ }^{*} p<0.05$ vs. vehicle; ${ }^{* *} p<0.01$ vs. vehicle; ${ }^{\star \star *} p<0.001$ vs. vehicle.

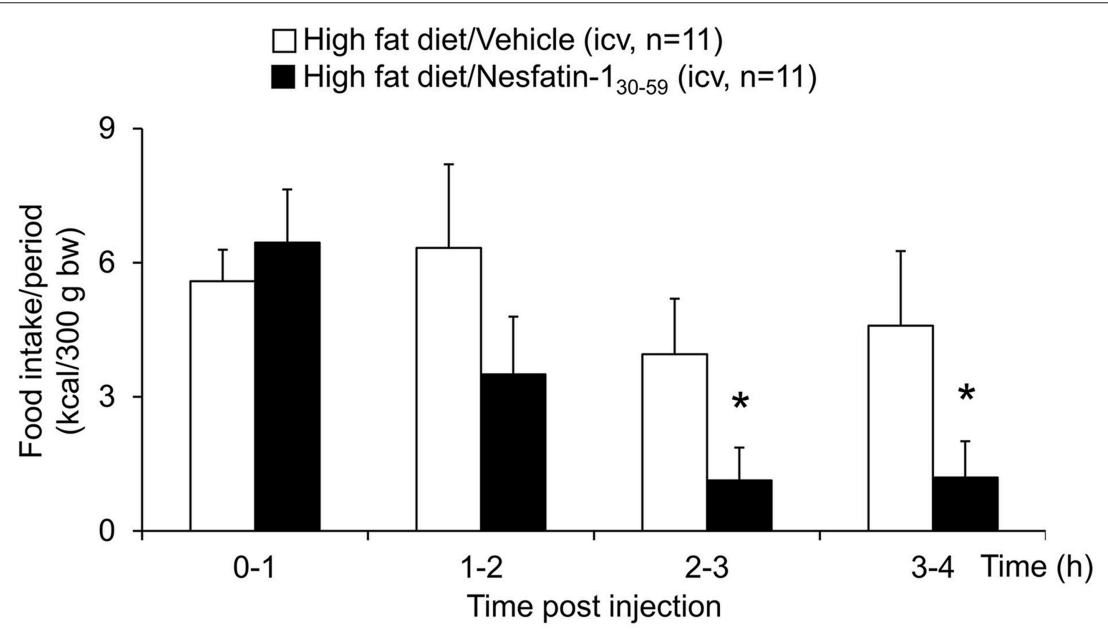

FIGURE 6 | Nesfatin-130-59 reduces food intake in the third and fourth hour post icv injection in diet-induced obese rats. Nesfatin-1 $30-59$ injected intracerebroventricularly $(0.9 \mathrm{nmol} / \mathrm{rat})$ decreased dark phase food intake in ad libitum fed rats during the third and fourth hour post injection compared to vehicle $(5 \mu \mathrm{l}$ $\mathrm{dd} \mathrm{H}_{2} \mathrm{O}$ ). Food intake was assessed using an automated episodic food intake monitoring system and expressed as food intake (kcal/300 $\mathrm{g}$ bw) $/ 1 \mathrm{~h}$ periods. Each bar represents the mean \pm sem. ${ }^{*} p<0.05$ vs. vehicle. 
TABLE 5 | Nesfatin-1 ${ }_{30-59}$ injected icv before the dark phase does not alter parameters of the first meal in diet-induced obese rats fed ad libitum with high fat diet.

\begin{tabular}{|c|c|c|}
\hline \multirow[t]{2}{*}{ Parameter } & \multicolumn{2}{|c|}{ Group } \\
\hline & Vehicle $\left(5 \mu\right.$ l dd $\mathrm{H}_{2} \mathrm{O}$ icv) & Nesfatin-1 $30-59(0.9 \mathrm{nmol}$ icv) \\
\hline Latency to first meal (min) & $14.74 \pm 6.05$ & $16.62 \pm 9.99$ \\
\hline Size of first meal (kcal/300 g bw) & $5.98 \pm 0.46$ & $6.36 \pm 0.89$ \\
\hline Duration of first meal (min) & $12.96 \pm 3.11$ & $13.54 \pm 2.85$ \\
\hline Eating rate of first meal (cal/300 g bw/min) & $71.91 \pm 8.76$ & $60.26 \pm 12.93$ \\
\hline Inter-meal interval (min) & $80.66 \pm 9.92$ & $128.10 \pm 24.60$ \\
\hline Satiety ratio after first meal (min/kcal/300 g bw food eaten) & $13.76 \pm 1.77$ & $22.50 \pm 5.00$ \\
\hline
\end{tabular}

icv, intracerebroventricular; mean \pm sem; $n=11$ group; $p>0.05$.

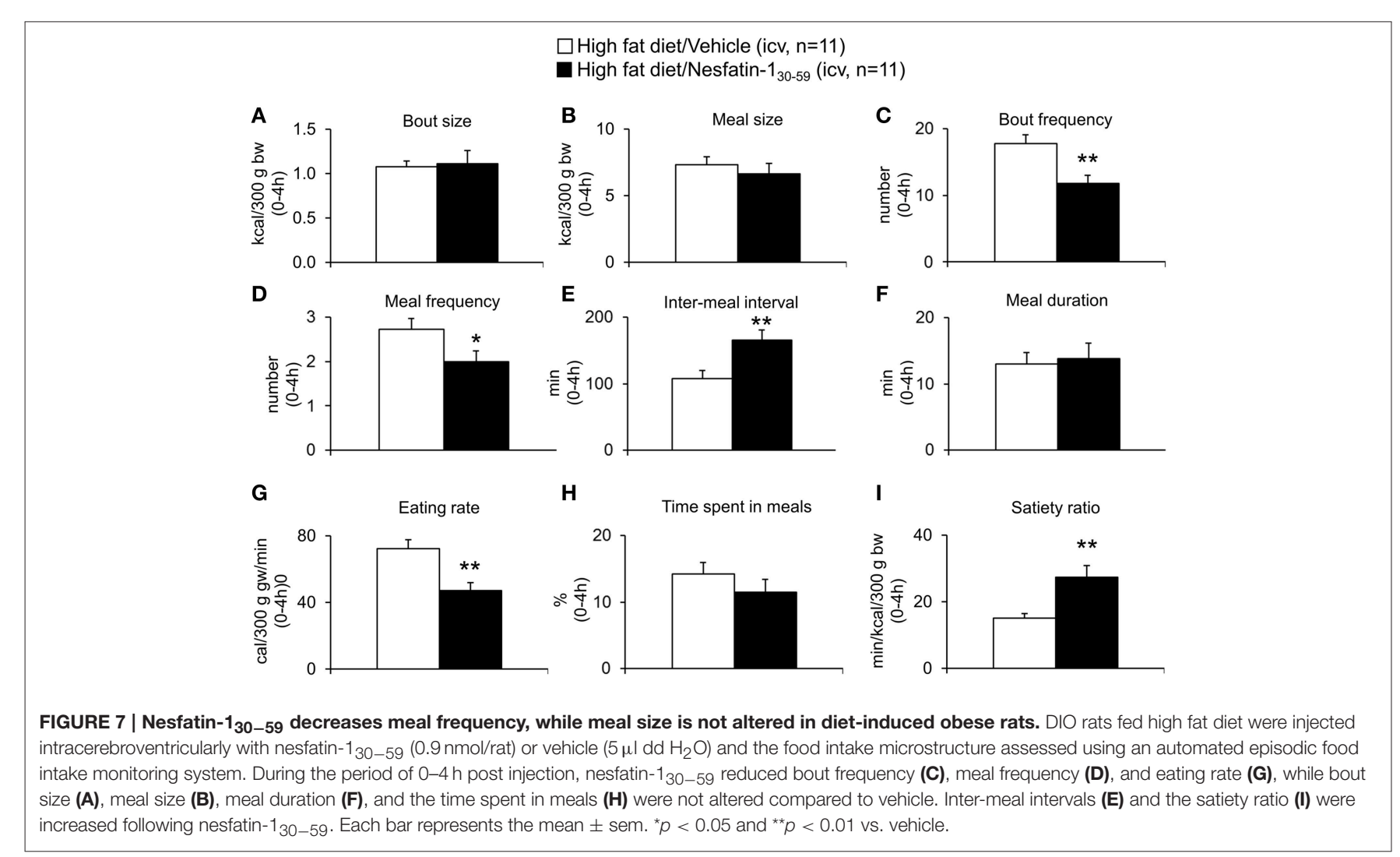

release of anorexigenic signals such as peptide YY (Xu et al., 2011) is blunted under these condition which is likely to result in reduced anorexigenic signaling. Therefore, we investigated the effect of nesfatin- $1_{30-59}$ also in DIO rats fed a high fat diet. The anorexigenic effect of nesfatin- $1_{30-59}$ was retained in DIO rats with a delayed onset (parameters of the first meal were not changed) and a long duration of action. Interestingly, the main food intake inhibitory effect was already observed during the third hour post injection $(-71 \%)$, while in normal weight rats the main reduction occurred later in the fifth hour post nesfatin-130-59 icv injection (-75\%). Moreover, the effect translated into a reduction of food intake over a $20 \mathrm{~h}$ period $(-13 \%)$, while in normal weight rats the effect lasted for $20 \mathrm{~h}$
$(-12 \%)$. Lastly, the underlying food intake microstructure was different in DIO rats compared to normal weight rats with a decrease in meal frequency and an unaltered meal size under conditions of high fat feeding indicating an increase of satiety while satiation is not altered. Taken together, these findings give rise to differential receptor binding, altered diffusion and-most importantly-point toward a differential downstream signaling under conditions of DIO compared to normal weight rats.

Interestingly, it was recently shown that rats fed a high fat diet display significantly lowered plasma NUCB2/nesfatin1 levels (Haghshenas et al., 2014; Mohan et al., 2014). Although the cellular action on the so far unknown receptor is yet to be established, the chronically reduced circulating 
NUCB2/nesfatin-1 levels may result in a sensitization of the receptor and lead to a stronger/more rapid response to icv nesfatin- $1_{30-59}$. Early on, it was shown that nesfatin- $1_{1-82}$ acts in a leptin-independent fashion (Oh-I et al., 2006; Maejima et al., 2009). However, the corticotropin releasing factor (CRF) receptor 2 , shown to play a role in nesfatin- $1_{1-82}$ 's anorexigenic signaling under normal weight conditions (Stengel et al., 2009a), may be important under DIO conditions as well. An earlier study showed that brain injection of the selective $\mathrm{CRF}_{2}$ agonist, urocortin 3 $(1 \mu \mathrm{g} / \mathrm{rat})$ reduced food intake with a delayed onset (between 3 and $4 \mathrm{~h}$ ) by decreasing meal frequency while meal size was not altered in rats (Fekete et al., 2007), a pattern very similar to the one observed following icv nesfatin- $1_{30-59}$ observed under DIO conditions in the present study. The predominance of the $\mathrm{CRF}_{2}$ downstream signaling pathway in the mediation of nesfatin-1 $1_{30-59}$ 's anorexigenic action might result from reduced processing of POMC to $\alpha-\mathrm{MSH}$ under conditions of obesity due to reduced prohormone convertase two levels (Çakir et al., 2013).

\section{REFERENCES}

Al Massadi, O., Lear, P. V., Müller, T. D., Lopez, M., Dieguez, C., Nogueiras, R., et al. (2014). Review of novel aspects of the regulation of ghrelin secretion. Curr. Drug Metab. 15, 398-413. doi: 10.2174/1389200215666140505153723

Ariyasu, H., Takaya, K., Hosoda, H., Iwakura, H., Ebihara, K., Mori, K., et al. (2002). Delayed short-term secretory regulation of ghrelin in obese animals: evidenced by a specific RIA for the active form of ghrelin. Endocrinology 143, 3341-3350. doi: 10.1210/en.2002-220225

Atsuchi, K., Asakawa, A., Ushikai, M., Ataka, K., Tsai, M., Koyama, K., et al. (2010). Centrally administered nesfatin-1 inhibits feeding behaviour and gastroduodenal motility in mice. Neuroreport 21, 1008-1011. doi: 10.1097/wnr.0b013e32833f7b96

Azzara, A. V., Sokolnicki, J. P., and Schwartz, G. J. (2002). Central melanocortin receptor agonist reduces spontaneous and scheduled meal size but does not augment duodenal preload-induced feeding inhibition. Physiol. Behav. 77, 411-416. doi: 10.1016/S0031-9384(02)00883-1

Berthoud, H.-R., Sutton, G. M., Townsend, R. L., Patterson, L. M., and Zheng, H. (2006). Brainstem mechanisms integrating gut-derived satiety signals and descending forebrain information in the control of meal size. Physiol. Behav. 89, 517-524. doi: 10.1016/j.physbeh.2006.08.018

Çakir, I., Cyr, N. E., Perello, M., Litvinov, B. P., Romero, A., Stuart, R. C., et al. (2013). Obesity induces hypothalamic endoplasmic reticulum stress and impairs proopiomelanocortin (POMC) post-translational processing. J. Biol. Chem. 288, 17675-17688. doi: 10.1074/jbc.M113.475343

Chen, X., Dong, J., and Jiang, Z.-Y. (2012). Nesfatin-1 influences the excitability of glucosensing neurons in the hypothalamic nuclei and inhibits the food intake. Regul. Pept. 177, 21-26. doi: 10.1016/j.regpep.2012.04.003

Crujeiras, A. B., Carreira, M. C., Cabia, B., Andrade, S., Amil, M., and Casanueva, F. F. (2015). Leptin resistance in obesity: an epigenetic landscape. Life Sci. 140, 57-63. doi: 10.1016/j.lfs.2015.05.003

Dong, J., Guan, H.-Z., Jiang, Z.-Y., and Chen, X. (2014). Nesfatin-1 influences the excitability of glucosensing neurons in the dorsal vagal complex and inhibits food intake. PLoS ONE 9:e98967. doi: 10.1371/journal.pone.0098967

Fekete, E. M., Inoue, K., Zhao, Y., Rivier, J. E., Vale, W. W., Szücs, A., et al. (2007). Delayed satiety-like actions and altered feeding microstructure by a selective type 2 corticotropin-releasing factor agonist in rats: intrahypothalamic urocortin 3 administration reduces food intake by prolonging the post-meal interval. Neuropsychopharmacology 32, 1052-1068. doi: 10.1038/sj.npp.1301214

Geary, N. (2005). A new way of looking at eating. Am. J. Physiol. Regul. Integr. Comp. Physiol. 288, R1444-R1446. doi: 10.1152/ajpregu.00066.2005
In conclusion, these results provide pharmacological evidence that nesfatin- $1_{30-59}$ is the active core of full length nesfatin$1_{1-82}$ also in rats that reduces food intake in normal weight rats fed standard rodent diet as well as DIO rats fed a high fat diet. Interestingly, the food intake microstructure differs with an increase of satiation under normal weight and an induction of satiety under DIO conditions. This may result from a downstream nesfatin- $1_{30-59} \rightarrow$ oxytocin $\rightarrow$ POMC $\rightarrow \alpha-$ $\mathrm{MSH} /$ melanocortin receptor $3 / 4$ signaling in normal weight rats while in DIO rats the nesfatin- $1_{30-59} \rightarrow \mathrm{CRF} / \mathrm{CRF}_{2}$ pathway may predominate. The effect of nesfatin- $1_{30-59}$ is centrally mediated as ip injection of higher doses had no effect. Therefore, the main effect of peripheral nesfatin-1 remains to be established.

\section{ACKNOWLEDGMENTS}

German Research Foundation STE 1765/3-1, Sonnenfeld Foundation, Charité University Funding UFF 89/441-176 (AS).
Goebel, M., Stengel, A., Wang, L., and Taché, Y. (2011). Central nesfatin-1 reduces the nocturnal food intake in mice by reducing meal size and increasing inter-meal intervals. Peptides 32, 36-43. doi: 10.1016/j.peptides.2010.09.027

Gonzalez, R., Kerbel, B., Chun, A., and Unniappan, S. (2010). Molecular, cellular and physiological evidences for the anorexigenic actions of nesfatin-1 in goldfish. PLoS ONE 5:e15201. doi: 10.1371/journal.pone.0015201

Haghshenas, R., Jafari, M., Ravasi, A., Kordi, M., Gilani, N., Shariatzadeh, M., et al. (2014). The effect of eight weeks endurance training and high-fat diet on appetite-regulating hormones in rat plasma. Iran. J. Basic Med. Sci. 17, 237-243.

Hellström, P. M. (2013). Satiety signals and obesity. Curr. Opin. Gastroenterol. 29, 222-227. doi: 10.1097/MOG.0b013e32835d9ff8

Kerbel, B., and Unniappan, S. (2012). Nesfatin-1 suppresses energy intake, colocalises ghrelin in the brain and gut, and alters ghrelin, cholecystokinin and orexin mRNA expression in goldfish. J. Neuroendocrinol. 24, 366-377. doi: 10.1111/j.1365-2826.2011.02246.x

Könczöl, K., Pintér, O., Ferenczi, S., Varga, J., Kovács, K., Palkovits, M., et al. (2012). Nesfatin-1 exerts long-term effect on food intake and body temperature. Int. J. Obes. 36, 1514-1521. doi: 10.1038/ijo.2012.2

Lutz, T. A., and Woods, S. C. (2012). Overview of animal models of obesity. Curr. Protoc. Pharmacol. Chapter 5, Unit 5.61. doi: 10.1002/0471141755.ph0561s58

Maejima, Y., Sedbazar, U., Suyama, S., Kohno, D., Onaka, T., Takano, E., et al. (2009). Nesfatin-1-regulated oxytocinergic signaling in the paraventricular nucleus causes anorexia through a leptin-independent melanocortin pathway. Cell Metab. 10, 355-365. doi: 10.1016/j.cmet.2009.09.002

Mohan, H., Ramesh, N., Mortazavi, S., Le, A., Iwakura, H., and Unniappan, S. (2014). Nutrients differentially regulate nucleobindin-2/nesfatin-1 in vitro in cultured stomach ghrelinoma (MGN3-1) cells and in vivo in male mice. PLoS ONE 9:e115102. doi: 10.1371/journal.pone.0115102

Nakata, M., and Yada, T. (2013). Role of NUCB2/nesfatin-1 in glucose control: diverse functions in islets, adipocytes and brain. Curr. Pharm. Des. 19, 6960-6965. doi: 10.2174/138161281939131127130112

Oh-I, S., Shimizu, H., Satoh, T., Okada, S., Adachi, S., Inoue, K., et al. (2006). Identification of nesfatin-1 as a satiety molecule in the hypothalamus. Nature 443, 709-712. doi: 10.1038/nature05162

Pan, W., Hsuchou, H., and Kastin, A. J. (2007). Nesfatin-1 crosses the blood-brain barrier without saturation. Peptides 28, 2223-2228. doi: 10.1016/j.peptides.2007.09.005

Paxinos, G., and Watson, C. (2006). The Rat Brain in Stereotaxic Coordinates. London, UK: Academic Press.

Schwartz, M. W., Woods, S. C., Porte, D., Seeley, R. J., and Baskin, D. G. (2000). Central nervous system control of food intake. Nature 404, 661-671. doi: $10.1038 / 35007534$ 
Shimizu, H., Oh-I, S., Hashimoto, K., Nakata, M., Yamamoto, S., Yoshida, N., et al. (2009). Peripheral administration of nesfatin-1 reduces food intake in mice: the leptin-independent mechanism. Endocrinology 150, 662-671. doi: 10.1210/en.2008-0598

Stengel, A., Coskun, T., Goebel, M., Wang, L., Craft, L., Alsina-Fernandez, J., et al. (2010a). Central injection of the stable somatostatin analog ODT8-SST induces a somatostatin2 receptor-mediated orexigenic effect: role of neuropeptide Y and opioid signaling pathways in rats. Endocrinology 151, 4224-4235. doi: 10.1210/en.2010-0195

Stengel, A., Goebel, M., Wang, L., Rivier, J., Kobelt, P., Mönnikes, H., et al. (2009a). Central nesfatin-1 reduces dark-phase food intake and gastric emptying in rats: differential role of corticotropin-releasing factor2 receptor. Endocrinology 150, 4911-4919. doi: 10.1210/en.2009-0578

Stengel, A., Goebel, M., Wang, L., Rivier, J., Kobelt, P., Mönnikes, H., et al. (2010b). Selective central activation of somatostatin receptor 2 increases food intake, grooming behavior and rectal temperature in rats. J. Physiol. Pharmacol. 61, 399-407.

Stengel, A., Goebel, M., Yakubov, I., Wang, L., Witcher, D., Coskun, T., et al. (2009b). Identification and characterization of nesfatin-1 immunoreactivity in endocrine cell types of the rat gastric oxyntic mucosa. Endocrinology 150, 232-238. doi: 10.1210/en.2008-0747

Stengel, A., Goebel-Stengel, M., Wang, L., Kato, I., Mori, M., and Taché, Y. (2012a). Nesfatin-1(30-59) but not the N- and C-terminal fragments, nesfatin-1(1-29) and nesfatin-1(60-82) injected intracerebroventricularly decreases dark phase food intake by increasing inter-meal intervals in mice. Peptides 35, 143-148. doi: $10.1016 /$ j.peptides.2012.03.015

Stengel, A., Hofmann, T., Goebel-Stengel, M., Lembke, V., Ahnis, A., Elbelt, U., et al. (2013a). Ghrelin and NUCB2/nesfatin-1 are expressed in the same gastric cell and differentially correlated with body mass index in obese subjects. Histochem. Cell Biol. 139, 909-918. doi: 10.1007/s00418-013-1087-8

Stengel, A., Mori, M., and Taché, Y. (2013b). The role of nesfatin-1 in the regulation of food intake and body weight: recent developments and future endeavors. Obes. Rev. 14, 859-870. doi: 10.1111/obr.12063

Stengel, A., and Taché, Y. (2012b). Gastric peptides and their regulation of hunger and satiety. Curr. Gastroenterol. Rep. 14, 480-488. doi: 10.1007/s11894-0120291-3
Strubbe, J. H., and Woods, S. C. (2004). The timing of meals. Psychol. Rev. 111 128-141. doi: 10.1037/0033-295X.111.1.128

Teuffel, P., Wang, L., Goebel-Stengel, M., Prinz, P., Kobelt, P., Scharner, S., et al. (2015). Treatment with ghrelin-O-acyltransferase (GOAT) inhibitor GoCoA-Tat reduces food intake by reducing meal frequency in rats. J. Physiol. Pharmacol. 66, 493-503.

Velloso, L. A., and Schwartz, M. W. (2011). Altered hypothalamic function in diet-induced obesity. Int. J. Obes. 35, 1455-1465. doi: 10.1038/ijo.2011.56

Xia, Z.-F., Fritze, D. M., Li, J.-Y., Chai, B., Zhang, C., Zhang, W., et al. (2012). Nesfatin-1 inhibits gastric acid secretion via a central vagal mechanism in rats. Am. J. Physiol. Gastrointest. Liver Physiol. 303, G570-G577. doi: 10.1152/ajpgi.00178.2012

$\mathrm{Xu}$, J., McNearney, T. A., and Chen, J. D. (2011). Impaired postprandial release/syntheses of ghrelin and PYY(3-36) and blunted responses to exogenous ghrelin and PYY(3-36) in a rodent model of diet-induced obesity. J. Gastroenterol. Hepatol. 26, 700-705. doi: 10.1111/j.1440-1746.2010.06563.x

Yosten, G. L. C., and Samson, W. K. (2009). Nesfatin-1 exerts cardiovascular actions in brain: possible interaction with the central melanocortin system. Am. J. Physiol. Regul. Integr. Comp. Physiol. 297, R330-R336. doi: 10.1152/ajpregu.90867.2008

Yosten, G. L. C., and Samson, W. K. (2010). The anorexigenic and hypertensive effects of nesfatin-1 are reversed by pretreatment with an oxytocin receptor antagonist. Am. J. Physiol. Regul. Integr. Comp. Physiol. 298, R1642-R1647. doi: 10.1152/ajpregu.00804.2009

Conflict of Interest Statement: The authors declare that the research was conducted in the absence of any commercial or financial relationships that could be construed as a potential conflict of interest.

Copyright (C) 2015 Prinz, Teuffel, Lembke, Kobelt, Goebel-Stengel, Hofmann, Rose Klapp and Stengel. This is an open-access article distributed under the terms of the Creative Commons Attribution License (CC BY). The use, distribution or reproduction in other forums is permitted, provided the original author(s) or licensor are credited and that the original publication in this journal is cited, in accordance with accepted academic practice. No use, distribution or reproduction is permitted which does not comply with these terms. 